\title{
IDH1 wt Allele
}

National Cancer Institute

\section{Source}

National Cancer Institute. IDH1 wt Allele. NCI Thesaurus. Code C77216.

The IDH1 wt Allele is located in the vicinity of 2q33.3 and is approximately $19 \mathrm{~kb}$ in length.

This allele, which encodes isocitrate dehydrogenase [NADP] cytoplasmic protein, plays a role in carbohydrate metabolism. 